УДК 165.63(4)"16/18"

DOI: $10.32837 /$ apfs.v0i24.854

Остап Михайлович Моравецький

аспірант кафедри історії філософії

Львівський національний університет імені Івана Франка, м. Львів, Україна

moravosta@gmail.com

\title{
ФІЛОСОФСЬКО-СВІТОГЛЯДНА ПРОБЛЕМА РАЦІОНАЛЬНОСТІ
}

Анотація. У статті розглянуто особливості генезису та еволюції філософського осмислення феномену раціональності. Показано, що у своїй сутності, у своїх витоках проблема раціональності постає як філософсько-світоглядна, оскільки виявляється тісно пов'язаною із усвідомленням людиною свого буття, меж своїх пізнавальних можливостей. Раціональність виявляється одним із можливих типів ставлення людини до світу, більше того вона є тим важливим елементом, який споріднює людину із Всесвітом, законами його функціонування.

Встановлено, що найважливішою умовою критичного аналізу проблеми раціональності виступає іï розгляд у широкому історико-філософському контексті. Обгрунтовано, що зазначений підхід допомогає уникнути доволі поширеної абсолютизації наукової раціональності як певної ціннісної позиції в сучасній культурі, що елімінує з науки моральні та естетичні начала, людину з її реальними проблемами і турботами.

Показано, що «історія» раціональності рухається від «первісної простоти» iii розуміння в Античності до складності сучасного трактування, що акцентує різноманіття іiі форм. Показано, що з другої половини XX-го століття проблема раціональності набуває рис самостійності і послідовно розробляється постпозитивістськими філософами науки.У зв'язку з цим, філософське осмислення питання про існування раціональності грунтується на поняттях iï ідеалів і типів, різноманіття форм існування. Виявлено природу і механізми розвитку історичних типів раціональності. Розглянуто ключові ідеї раціональності в європейській філософській традиції.

Показано, що сучасна парадигма науки формується через сукупність філософських, загальнотеоретичних основ, що $є$ системою понять i уявлень, теоретичних схем та метатеорій, які в кінцевому результаті покликані стимулювати розвиток нових ідей і нових технологій. У зв'язку з цим, філософсько-наукове осмислення питання про існування наукової раціональності грунтується на поняттях ¥ї ідеалів і типів, різноманітті форм існування. Виходячи 3 отриманих результатів, визначено структуру інваріантного філософського уявлення про раціональність.

Ключові слова: світогляд, раціональність, наука, філософія, пізнання.

\section{1. ВСТУП}

Постановка проблеми. $\mathrm{y}$ своїй сутності, у своїх витоках проблема раціональності постає як філософсько-світоглядна, оскільки виявляється тісно пов'язаною із усвідомленням людиною свого буття, меж своїх пізнавальних можливостей. Раціональність виявляється як один із можливих типів ставлення людини до світу, більше того вона є тим важливим елементом, який споріднює людину із Всесвітом, законами його функціонування.

У зв'язку з цим, будь-яке окреслення проблеми раціональності - чи це 3 точки зору логіки, чи історії науки чи ін. передбачає звернення до філософсько-світоглядних джерел іiі осмислення, що задають необхідну перспективу дослідження. При такому підході дана проблема відкривається в іiі граничних межах, як феномен духовної культури людства. Таким чином раціональність, як вища культурна цінність може бути розглянута в певних нормах людської поведінки, в проектуванні людської діяльності, зрештою виступати орієнтиром людини у світі. 
Проблему раціональності в філософії науки піднімали як зарубіжні автори такі як Л. Вітгенштейн, Т. Кун, І. Лакатос, Л. Лаудан, Н. Решер, Р. Сельє, Дж. Серль, Ф. де Соссюр та інші, зокрема російські - В. Візгін, А. Кравець, Л. Маркова, Н. Овчинніков, А. Ракітов, 3. Сокулер та інші, так і вітчизняні вчені - I. Бичко, М. Бургін, В. Горський, Н. Депенчук, Г. Добров, . Добронравова, Л. Дротянко, К. Жоль, Г.Заїченко, А.Ішмуратов, І.Огородник, Л.Озадовська, В.Окороков, Б. Парахонський, М. Парнюк, С. Повторева, В. Ратніков, В. Рижко, Т. Суходуб, О. Терешкун, В. Чуйка та багато інших.

Логіко-методологічний розгляд раціональності міститься в роботах таких авторів, як Н. Автономова, В. Алексеєв, Ю. Івлєв， В. Касавін，В. Лекторський， М. Мудрагей, Е. Нікітін, К. Поппер, В. Порус, Р. Рузавін, М. Розов, К. Рутманіс, В. Швирьов. Проблема типологізації раціональності отримала висвітлення в працях В. Гайденко, П. Гайденко, Т. Ленка, О. Леонтьєвої, М. Мамардашвілі, Т. Романовської, Г. Смирнова, Н. Смирнової, В. Стьопіна. Аксіологічний аспект раціональності був досліджений А. Кравченко, А. Нікіфоровим, В. Порусом, Г. Л. Тульчинським та ін.

Проекти «нової» раціональності були в різний час запропоновані або проаналізовані такими авторами, як Р. Башляр, П. Бурдьє, Р. Гачев, П. Гуревич, А. Новіков, В. Порус, П. Фейерабенд, К. Хюбнер.

Метою дослідження є розкриття особливостей генези та еволюції філософськосвітоглядної проблеми раціональності.

Реалізація цієї мети передбачає розв'язання таких завдань:

- виявити природу і механізми розвитку історичних типів раціональності;

- розглянути ключові ідеї раціональності в європейській філософській традиції;

- виходячи 3 отриманих результатів, визначити структуру інваріантного філософського уявлення про раціональність.

\section{2. РЕЗУЛЬТАТИ ДОСЛІДЖЕННЯ}

Важливою умовою критичного аналізу проблеми раціональності виступає іiі розгляд у широкому історико-філософському контексті. Дослідження генезису та еволюції ідеї раціональності в історії філософської думки задає таке поле аналізу цього феномена, що дозволяє розглянути його як єдність та різноманіття історичних форм. Даний підхід допоможе уникнути доволі поширеної абсолютизації наукової раціональності як певної ціннісної позиції в сучасній культурі, що елімінує з науки моральні та естетичні начала, людину з іiі реальними проблемами і турботами.

Постановка питання про раціональність органічно пов'язана 3 природою філософії, предметом та методологією її пошуків як раціоналізованої форми світогляду, що відрізняє іiі від релігії, міфології, естетико-художнього сприйняття світу. Саме тому, питання про можливості раціонального осмислення і вирішення корінних світоглядних проблем, таких як ставлення людини до світу і світу до людини, раціонального пізнання Буття, Універсуму, Абсолюту та багатьох інших, окреслювались в історії людської думки не просто як одні з найбільш важливих кардинальних філософських питань, а як проблема сенсу існування самої філософії, меж іiі можливостей.

Щодо історії проблеми, то походження поняття «раціональність» сходить до латинського слова «ratio» (рахунок, перелік, сума тощо). В силу початкової багатозначності поняття в філософії існує безліч поглядів на раціональність, при відсутності загальноприйнятого визначення і суворого методологічного вирішення іiі проблеми, що навіть спонукає деяких вчених взагалі відмовитися від вживання аналізу даного поняття. При спробі визначити поняття «раціональність» стикаються із всіма можливими логічними помилками - «замкнуте коло», визначення «невідомого через 
невідоме» і т. ін. У той же час, вказуючи на межі раціональності, говорять про логічність, доцільність, простоту, ефективність, узгодженість.

Для того щоб простежити, як виникла ця проблема, необхідний екскурс в історію iї становлення, яка сягає своїми коренями в філософію античної Греції, де Парменідом була вперше сформульована теза про тотожність буття і мислення, наслідком чого був збіг структур буття i розуму. 3 цього випливає вимога раціональності, на якій наголошує античність (в особі Аристотеля) і яка вказує на те, що «правильність» форм мислення є необхідною умовою пізнання реальності. Таким чином, вищим досягненням античного філософського дискурсу стало виникнення логіки. Термін «логос», що дав назву новій науці, семантично зводить воєдино мову і онтологію. Для стародавніх греків структури мови, думки і буття - єдині, а раціональність $є$ основою Розуму, за межами якого нічого немає. Отже, ідеал раціональності в цей період збігається 3 абсолютним незмінним Розумом.

У середньовіччі (Й. С. Еріугена, А. Кентерберійський, П. Абеляр, Тома Аквінський) раціональність розглядається у співвідношенні розуму і віри. Якщо у Аристотеля основним суб'єктом пізнання була «душа», яка причетна до властивостей нескінченного Божественного розуму за допомогою мислення, то в Середні віки єдиним джерелом пізнавальної активності є Бог, незбагненний для людського розуму. Доступним є лише Його Слово - «Логос», яке стає основним об'єктом пізнання. Визнання джерелом раціональності «ірраціонального», непізнаваного Бога радикально відрізняє середньовічну думку від простої античної тотожності буття і мислення. Так, вперше раціональність збагачується «самовизнанням» неможливості вивести свої власні підстави з самої себе. У середньовічній думці виникає «зародок» раціональності Нового часу: поділ процесу пізнання на суб'єкт і об'єкт.

Реформація, побачивши знак божественного обрання в добробуті, заклала тим самим культурні підстави для пост-реформаційної вимоги вивчення, поряд з Книгою Писання, i «Книги Природи» (Ф. Бекон), чим підготувала грунт для науки Нового часу, в якій раціональність вперше стає синонімом «науковості».

Філософія Нового часу (Р. Декарт, Ф. Бекон, Т. Гоббс, Г. Ляйбніц, Б. Спіноза, І. Кант, Г. В. Ф. Гегель) закладає ідеї абсолютного розуму, що є універсальним засобом пізнання реальності та впорядкування соціального буття. Основними рисами ії стають: 1) розкол на суб'єкт і об'єкт; 2) механічність; 3) експеримент; 4) відношення панування над природою. Людина, ставлячи себе на місце суб'єкта, що пізнає, зрівнює себе 3 Богом. В результаті розсудок і розум ототожнюються, оскільки якщо суб'єкт, що пізнає у стані «випробувати» природу, то відпадає необхідність в античному розумі як здатності «інтелектуальної інтуїції», що проникає безпосередньо в буття і «схоплює» його цілісність i єдність. Але розкол пізнання на «допитуючий» суб'єкт i «допитуваний» об'єкт в результаті привів і до розколу буття, що знайшло вираження, 3 одного боку, в дуалізмі Р. Декарта, з іншого ж - у спробі емпіристів звести пізнання до чуттєвого досвіду, що призвело до юмового заперечення можливості раціональності (i «науковості») взагалі.

Нову спробу вирішити проблему раціональності, досліджуючи іï структуру, робить I. Кант, для чого він пропонує розрізняти два способи застосування розуму: формально-логічний та трансцендентальний. Проте Кант, проголосивши, що ми здатні пізнати тільки те, що самі «сконструювали» за допомогою апріорних форм нашого розсудку і розуму, не зміг до кінця вирішити проблему Декарта, допустивши існування «речей-в-собі». Крім того, що Кант не знайшов заново втраченої єдності буття i мислення, він не врахував ще і ту обставину, що трансцендентальні структури розуму можуть еволюціонувати. Проте заслуга філософа в тому, що він вперше представив раціональність як діяльність суб'єкта, що пізнає. 
Г. В. Ф. Гегель, прагнучи усунути «річ-у-собі», мислить раціональність як основну властивість Абсолютної Ідеї, яка ототожнюється ним з Світовим Розумом, що виглядає як спроба відродити античну тотожність буття і мислення. Для цього Гегель винаходить новий спосіб мислення - діалектичну логіку, проголосивши основним рушієм думки не прагнення до єдності (тотожності), а протиріччя, що обернулося обмеженням можливостей формальної логіки - основи античної раціональності.

Діалектичний матеріалізм зосередив особливу увагу на генезі раціональності, категорії суть якої поняття людського мислення, що відображають закони об’єктивного матеріального світу шляхом багаторазового повторення різних логічних фігур. Проте тут криється суперечність: визнаючи активність суб'єкта в пізнавальному процесі, діамат трактує сам цей процес як відображення природи, тим самим одночасно виключаючи з нього суб'єкт, що пізнає.

Найбільші представники «ірраціоналізму» - С. К’єркегор, А. Шопенгауер, Ф. Ніцше - взагалі ставили під сумнів цінність раціонального пізнання, протиставляючи йому «стрибок» до віри, «світову волю» або «волю до влади». В кінці XIX століття раціональність відходить на задній план філософського «мейнстріму».

Наступні представники антисцієнтизму знову цікавляться проблемою раціональності, з тією лише різницею, що вони шукають іiі не в науковому дискурсі, а у філософсько-художньому мисленні. Звідси виникає ідея, що «чистої» раціональності, без домішки ірраціонального компонента, не може бути. Н. Бердяєв критикує сцієнтистську раціональність за ії вивідний характер, за «погану нескінченність» раціонального мислення, не здатного дати самому собі власні підстави, підкреслюючи необхідність віри та інтуїції для наукового пізнання. К. Г. Юнг вказує на принципову «посередність» раціональності, іï «пристосувальницький», нетворчий характер.

Серед апологетів раціонального мислення слід назвати М. Вебера, на думку якого раціональність є визначальною рисою сучасної європейської цивілізації, якій Європа «зобов'язана» процесом «розчаклування світу», що призвело до виникнення капіталізму - раціонально організованого способу господарювання. Вебер схильний розглядати раціональність в якості суб'єкта, а не предиката людської діяльності. В результаті раціональність виступає як «оптимальність», як відповідність засобів до мети, що дозволяє розрізняти «ціннісну» і «цільову» раціональності. Таким чином, раціональність починає «множитися», диференціюватися. Одним з предтеч покладання «множинності» типів раціональності виявився марксизм, відзначивши наявність у суспільстві класів-антагоністів, кожен 3 яких володіє властивою лише йому культурною «надбудовою», що включає в себе і характерні форми «правильного» мислення. Тенденцію до «розширення» поняття «раціональність» можна відзначити у К. Хюбнера, який, вказуючи на такі риси раціональності, як «пізнаваність, обгрунтованість, послідовність, ясність і загальнообов'язкова прийнятність», виділяє низку типів раціональності, виходячи з принципової інтерсуб'єктивності раціонального знання. Висновок: раціональність є щось формальне, що відноситься тільки до вже встановленого змістом, неважливо, науки, релігії чи міфу.

Подібні узагальнення, що протиставляють раціональність «науковості», викликали реакцію з боку позитивістів - демаркаціоністів, які виходять 3 положення, про те, що раціональна наука не може випливати 3 ірраціональної думки, що в результаті призводило до надмірного обмеження сфери «раціонального». Так, Т. Кун і К. Поппер розглядали раціональність, насамперед, як раціональність методології, пов'язаної з описом правил і норм діяльності вченого, до якої безпосередньо принципи раціональності незастосовні. Це спровокувало П. Фейєрабенда проголосити «методологічний анархізм», згідно якого в рівній мірі правомірними є різні типи 
раціональності, «єдність» же наукового пізнання пояснюється виключно конвенціоналізмом.

У зв'язку з цим, 3 другої половини XX-го століття проблема раціональності набуває рис самостійності і послідовно розробляється постпозитивістськими філософами науки. Спроби визначити раціональність через якийсь ії зразок знаходять своє вираження в проблемі демаркації. Логічні позитивісти головним критерієм наукової раціональності вважали доведеність і підтвердження знання (принцип верифікації). К. Поппер стверджує, що наукова діяльність раціональна до того моменту, доки iї результати можуть бути фальсифіковані, а форма раціонального мислення знаходить своє реальне втілення в критичній дискусії. І. Лакатос, переглядаючи «критичний раціоналізм» Поппера, наукову раціональність розглядає у зв'язку 3 «науково-дослідницькими програмами»: раціональність дії вченого, вважає він, залежить від його прихильності до конкретної дослідницької програми, це відбувається часом наперекір суперечностям та емпіричним аномаліям, які виникають в ході іiі розвитку. Т. Кун стверджує, що раціональність не зводиться ні до логіко-семантичного, ні до філософсько-методологічного аспектів. Замість цього він пропонує розглядати раціональність крізь призму парадигми і тісно пов'язаною з нею діяльністю наукових товариств. В результаті раціональність набуває контекстуальний характер, тобто залежить від конкретних парадигмальних установок, на які в свою чергу впливають конкретні історичні i соціокультурні характеристики. П. Фейерабенд зовсім проголошує теоретико-пізнавальний анархізм і принцип «все дозволено».

Зберегти «єдність» раціональності намагаються концепції, які вбачають можливість раціональної наукової дискусії в наявності «загального мовного каркасу і універсальної загальнозначимості логічних правил» (Р. Карнап). Інша спроба повернути втрачену єдність була зроблена німецьким соціальним філософом Ю. Хабермасом, на думку якого «існує лише одна... раціональність, яка полягає в тому, щоб виявляти загальне під різноманітністю пристрастей і забобонів». Ключове поняття у Хабермаса - це мовний дискурс, який він інтерпретує як раціональні форми аргументації, необхідні для аналізу суперечливих висловлювань.

У сучасній західній філософії знову спостерігається тенденція до узагальнення поняття «раціональність». Щоб врахувати всі наявні предикати цього поняття, до складу раціональності включаються елементи не - та ірраціонального.

Так Л. Лаудан виділяє дві моделі раціональності: ієрархічну і мережеву. Дж. Серль, який відстоює науковий реалізм, говорить про західну раціоналістичну традицію, в якій безпосередньо зв'язуються уявлення про реальність, раціональність і мову. С. Тулмін стоїть на позиціях гнучкої, наближеної до реальності раціональності, яка трактується ним з урахуванням тимчасових характеристик раціональності, що залежать від історичних періодів і норм дослідження.

\section{3. ВИСНОВКИ І ПЕРСПЕКТИВИ ПОДАЛЬШИХ ДОСЛІДЖЕНЬ}

Підводячи підсумок, можна сказати, що «історія» раціональності рухається від «первісної простоти» іiі розуміння в Античності до складності сучасного трактування, що акцентує різноманіття iï форм. Паралельно з цією тенденцією, постійно присутні спроби звести описувану «множинність» до нової, системної єдності. Основна складність полягає в тому, що сьогодні множинність не просто присутня у «зовнішньому» світі речевості, а стає невід'ємною частиною «передрозуміння» світу, в силу різноманіття наявних філософських «метанаративів» і відсутності «привілейованого» дискурсу. Відмінною рисою пізнавального процесу в «стані 
постмодерну» стає принципова множинність, притаманна як світу «речей», так і світу думки.

Сучасна парадигма науки формується через сукупність філософських, загальнотеоретичних основ, що $є$ системою понять і уявлень, теоретичних схем та метатеорій, які в кінцевому результаті покликані стимулювати розвиток нових ідей i нових технологій. У зв'язку $з$ цим, філософсько-наукове осмислення питання про існування наукової раціональності грунтується на поняттях іï ідеалів і типів, різноманітті форм існування.

\title{
СПИСОК ВИКОРИСТАНИХ ДЖЕРЕЛ
}

Канке В. А. Основные философские направления и концепции науки. Итоги ХХ ст. / В. Канке. - Москва : Логос, 2000. - 320 с.

Лук'янець В. С. Науковий світогляд на зламі століть / В. С. Лук'янець, О. М. Кравченко, Л. В. Озадовська та ін. - Київ, 2006. - 288 с.

Поппер К. Логика и рост научного знания / К. Поппер. Избранные работы. Москва : Прогресс, 1983. - 605 с.

Розин В. М. Типы и дискурсы научного мышления / В. М. Розин. - Москва : Едиториал УРСС, 2000. - 246 с.

Степин В. С. От классической к постнеклассической науке (изменение оснований и ценностных ориентаций) / В. С. Степин // Ценностные аспекты развития науки. Москва : Наука, 1990. - С. 152-166.

\section{ФИЛОСОФСКО-МИРОВОЗЗРЕНЧЕСКАЯ ПРОБЛЕМА РАЦИОНАЛЬНОСТИ}

\begin{abstract}
Аннотация. В статье рассмотрены особенности генезиса и эволюции философского осмысления феномена рациональности. Показано, что в своей сущности, в своих истоках проблема рациональности предстает как философско-мировоззренческая, поскольку оказывается тесно связанной с осознанием человеком своего бытия, предела своих познавательных возможностей. Установлено, что важнейшим условием критического анализа проблемы рациональности выступает ее рассмотрение в широком историкофилософском контексте. Показано, что «история» рациональности движется от «первоначальной простоты» ее понимания в Античности к сложности современной интерпретации, которая акцентирует многообразие ее форм. В связи с этим, философское осмысление вопроса о существовании рациональности основывается на понятиях ее идеалов и типов, многообразии форм существования. Выявлено природу и механизмы развития исторических типов рациональности. Рассмотрены ключевые идеи рациональности в европейской философской традиции. Исходя из полученных результатов, определена структура инвариантного философского представления о рациональности.
\end{abstract}

Ключевые слова: мировоззрение, рациональность, наука, философия, познание.

\section{THE PHILOSOPHICAL PROBLEM OF RATIONALITY}

Abstract. The article discusses the features of the genesis and evolution of philosophical understanding of the phenomenon of rationality. That is shown that in its essence, in its origins the problem of rationality arises as a philosophical and philosophical outlook, since it is closely connected with the awareness of the person of his being, beyond the limits of his cognitive abilities. Rationality appears as one of the possible types of human relation to the world, moreover it is the essential element that is related a man with the universe, the laws of its functioning. 
It is established that the most important problem of critical analysis of rationality in favor of its consideration in a broad historical and philosophical context. It is proved that this approach helps to avoid rather common scientific rationality as the absolute value of a position in contemporary culture which eliminates the moral and aesthetic principles of a science, a persoon with its real problems and concerns.

It is shown that the "history" of rationality moves from the "primitive simplicity" of its understanding in Antiquity to the complexity of modern interpretation, which emphasizes the diversity of its forms. It has been shown that since the second half of the 20th century the problem of rationality has acquired a trait of independence and has been consistently developed by postpositivist philosophers of this science In this regard, philosophical understanding of the question of the existence of rationality is based on the concepts of its ideals and types, the variety of forms of existence. The nature and mechanisms of development of historical types of rationality are revealed. Key ideas of rationality in the European philosophical tradition are considered.

It is shown that the modern paradigm of science is formed through a set of philosophical, general theoretical foundations, which is a system of concepts and concepts, theoretical schemes and metatheories, which are ultimately intended to stimulate the development of new ideas and new technologies. In this regard, the philosophical and scientific understanding of the question of the existence of scientific rationality is based on the concepts of its ideals and types, the variety of forms of existence.

Based on the obtained results, the structure of invariant philosophical conception of rationality is determined.

Keywords: world view, rationality, science, philosophy, knowledge. 